\title{
Agronomic properties and nutritional status of plum trees (Prunus domestica L.) influenced by different cultivars
}

\author{
T. Milošević1* ${ }^{*}$ N. Milošević ${ }^{2}$ and I. Glišić ${ }^{1}$ \\ ${ }^{1}$ Department of Fruit Growing and Viticulture, Faculty of Agronomy, University of Kragujevac, Cara Dusana 34, 32000 Cacak, \\ Serbia. ${ }^{2}$ Department of Pomology and Fruit Breeding, Fruit Research Institute Cacak, Kralja Petra I/9, 32000 Cacak, Serbia. \\ *Corresponding author: tomomilosevic@kg.ac.rs
}

\begin{abstract}
The tree growth, fruit weight and leaf mineral status of ten plum cultivars grafted on rootstock of autochthonous plum 'Belošljiva' under high density planting system (HDP) on acidic soil was investigated in the fifth and sixth leaf. Results indicated that tree vigour, fruit weight and productivity significantly depend on the cultivar. 'Čačanska Najbolja' had the most vigorous trees, while 'Čačanska Lepotica' had the smallest. The fruit weight was the highest in 'Čačanska Rana', and the lowest in 'd'Agen'. 'Stanley' was the most productive cultivar in 2006 and 'Čačanska Rodna' in 2007. Yield efficiency was the highest in 'Čačanska Lepotica' and the lowest in 'Ruth Gerstetter', 'Čačanska Rana', 'Čačanska Najbolja' and 'Opal', respectively. Significant differences were observed among cultivars for leaf major nutrient (N, P, K, Ca, Mg) levels at 120 DAFB. Larger imbalance of leaf major elements was observed in 'd'Agen', whereas good balance was found in 'Violeta'.
\end{abstract}

Keywords: Fruit weight, leaf nutrient content, plum, yield efficiency

\section{Introduction}

European plum (Prunus domestica L.) commonly known as "Šljiva" is an important commercial fruits, which has been traditionally cultivated in most of the areas of Serbia. Plum fruit are mainly marketed as fresh consumption as well as for drying. Also, main processed products made from plums include compotes, mousse, pulp, candied fruit, frozen fruit, jams, jelly products and traditional Serbian plum drink called "Rakija" or "Šljivovica" (Milosevic et al., 2010a). Serbian plum production in 2011 was 581,874 tons or $5.29 \%$ of the total world production (FAOSTAT, 2013), being the second largest world producer after China. In this context, plum is the most important fruit species in Serbia.

Plums in Serbia are grown throughout the country both in commercial orchards and home gardens. Extensive growing technology, low unstable yields, low-quality 
fruit, multitude of cultivars, and PPV-induced problems are main distinctions in plum production in Serbia (Milosevic et al., 2010b). This has resulted in low yield per tree of $8.6 \mathrm{~kg}$ (NenadovićMratinić et al., 2007a). In addition, the structure of the assortment of plums is unfavorable. About half of the total numbers of trees are native cultivars that have small fruits, followed by poor quality. On the other hand, over $75 \%$ of the plum orchards are located in mountain areas (Nenadović-Mratinić et al., 2007b). In these areas, the main limiting factor for intensive plum production is acidic soils with deficiency of organic matter and inadequate major nutrients availability. Appearance of nutrients deficiencies symptoms and responses to added nutrients indicated the prevalence of nutritional disorders of macronutrients. Therefore, limited vegetative growth, low productivity and poor fruit quality are presented in Serbian orchards (Milosevic and Milosevic, 2010).

Several techniques and methods have been developed in order to recognize and diagnose the nutrient disorder(s) caused by deficiency or excessive contents of essential macronutrients in fruit trees. Leaf analysis at 120 days after full bloom (DAFB) can be a very useful tool for plum nutritional diagnosis (Singh-Sidhu and Kaundal, 2005) and Deviation from Optimum Percentage (DOP index and $\Sigma$ DOP) have been proposed and used for this purpose (Montañés et al., 1991). However, little is known about the influence of plum cultivars grown in HDP system on leaf major nutrient content. The prognosis of leaf major element deficiencies by foliar analysis reading is usually performed too late in the growing season to efficiently apply correcting measures before harvesting (Sanz, 1999).

The present study was carried out to investigate tree vigour, productivity, fruit size and nutritional status of the leaves at 120 DAFB in ten plum cultivars grown under HDP system.

\section{Materials and Methods}

\subsection{Plant material}

Cultivars chosen for this study included four Serbian ('Čačanska Rana', 'Čačanska Lepotica', 'Čačanska Rodna', 'Čačanska Najbolja') and six introduced ('Ruth Gerstetter', 'Stanley', 'd'Agen', 'Opal', 'Bluefree', 'Violeta') plum cultivars. Cultivars were compared in one private orchard established in the February of 2001. This choice was due to the possible interest in these cultivars in the Cacak area, because of their maturity time and good fruit quality. Cultivars were grafted on rootstock of autochthonous plum cultivar 'Belošljiva' (P. domestica L.).

\subsection{Field trial, soil mineral status and weather conditions}

The trial was carried out at the village Prislonica ( $43^{\circ} 57^{\prime}$ N, $20^{\circ} 26^{\prime}$ E, $344 \mathrm{~m}$ a.s.l.), near Cacak city (Western Serbia), five and six years after planting (2006 and 2007). Trees were planted at HDP system with spaces of $4 \mathrm{~m} \times 2 \mathrm{~m}$; the training system was Spindle bush. This training system controlled tree height by pruning in the summer. The orchard was managed following the usual standard procedures, except irrigation, and fertilized with $400 \mathrm{~kg}$ of NPK (15:15:15) compound mineral fertilizer in autumn and with $300 \mathrm{~kg} \mathrm{ha}^{-1}$ of Calcium Ammonium Nitrate (CAN) containing 27\% of $\mathrm{N}_{\text {TOT }}$ prior to the onset of the growing season.

Soil mineral analyses carried out in autumn 2005 and 2006, before fertilization. Soil texture in plum orchard is sandy-loam, moderate in organic matter $(1.62 \%)$ and poor in total nitrogen $(0.14 \%)$. The contents of $\mathrm{P}_{2} \mathrm{O}_{5}$, $\mathrm{K}_{2} \mathrm{O}, \mathrm{CaO}$ and $\mathrm{MgO}$ were $178 \mathrm{mg} \mathrm{kg}^{-1}, 220 \mathrm{mg} \mathrm{kg}^{-1}$, $0.39 \%$ and $6.2 \mathrm{mg} \mathrm{kg}^{-1}$, respectively. Soil $\mathrm{pH}$ in 0.01 $\mathrm{M} \mathrm{KCl}$ was 4.86 . The soil major nutrients content is average values for two successive years.

The climate is maritime temperate with moderate to strong winters, and hot and semi to dry summers. Local rainfall averages between 500 and $600 \mathrm{~mm}$ per 
year mostly concentrated in late spring and in autumn. The annual average temperature is $11.3{ }^{\circ} \mathrm{C}$, whereas mean temperature for vegetative cycle is $17.0^{\circ} \mathrm{C}$.

\subsection{Measurements of tree vigour, fruit weight, productivity and leaf macronutrient content}

The following parameters were measured and/or calculated: trunk circumference at $10 \mathrm{~cm}$ above the graft union, the yield per tree (YT, kg) and yield efficiency (YE, $\mathrm{kg} \mathrm{cm}^{-2}$ ). The trunk circumferences were converted into trunk cross-sectional areas $\left(\mathrm{TCSA}, \mathrm{cm}^{2}\right)$. For a period of two harvest seasons, 25 fruits from each cultivar of each of four replicates were collected and fruit weight (FW, g) was measured using a Tehnica ET-1111 technical scale (Iskra, Horjul, Slovenia).

Cumulative yield per tree (CY, kg) and YE of each cultivar were computed from the harvest data. An ACS System Electronic Scale (Zhejiang, China) was used to measure fruit yield. The plant YE was expressed as the ratio of total CY in $\mathrm{kg}$ per final TCSA. The final TCSA was measured at the end of 2007.

Leaf major nutrients content were determined at 120 DAFB. Leaf samples were collected from the middle part of bearing shoots of the trees in five blocks. The mineral composition of the dried samples was measured using the standard laboratory methods. Leaf $\mathrm{N}$ content was determined by Kjeldahl method using Gerhardt Vapodest 50s equipment (Königswinter, Germany); P was analyzed spectrophotometrically by the phospho-vanadate colorimetric method (Hewlett Packard 8452A, Ontario, CA); K were determined by flame photometry (Corning 405, Corning, Halstead, UK), and $\mathrm{Ca}$ and $\mathrm{Mg}$ by atomic absorption spectroscopy (Pye Unicam SP 191, Cambridge, UK).

The DOP index was estimated for the diagnosis of the leaf mineral status of the trees (Montañés et al., 1991). The DOP index was calculated from the leaf analysis at 120 DAFB by the following mathematical equation:

$$
\text { DOP }=\frac{C \times 100}{C_{\text {ref }}}-100,
$$

where: $\mathrm{C}$ is the major element content in the sample to be studied, and Cref is the major nutrient content considered as optimum; both values were given on a dry weight basis. The Cref has been taken from optimum values, proposed by Shear and Faust (1980) for major nutrients in plum leaves. The $\Sigma$ DOP is obtained by adding the values of DOP index irrespective of sign. The larger the $\Sigma D O P$, the greater is the intensity of imbalances among nutrients.

\subsection{Data analysis}

Data obtained were statistically analyzed using analysis of variance (ANOVA) using $F$ test. The treatment means were compared using Duncan's multiple range test at $p \leq 0.05$, using the MSTAT-C statistical computer package (Michigan State University, East Lansing, MI, USA). The figure is performed by the Excel software (Microsoft Corporation, Roselle, IL, USA). All data, except TCSA and yield efficiency, are averages for 2006 and 2007.

\section{Results and Discussion}

\subsection{Tree vigour, fruit size and productivity}

Data in Table 1 indicated that mean TCSA were higher in 'Čačanska Najbolja' and 'Ruth Gerstetter', and lower in 'Čačanska Lepotica'. This result is in agreement with previous work in plum (Sosna, 2002), who reported that 'Čačanska Najbolja' had the highest TCSA in plum orchard established at $4 \mathrm{~m} \times 2 \mathrm{~m}$ spacing when compared with rest cultivars. Furthermore, Vitanova et al. (2004) reported that 'Čačanska Lepotica' and 'Stanley' had the moderate values of TCSA and 'Opal' the high. Meland (2005) and Peppelman et al. (2007) reported that TCSA of plum trees in HDP increased with increasing tree spacing and 'Opal' was the most vigorous, which confirmed our results. 
Table 1. Final trunk cross sectional area (TCSA), fruit weight, yield per tree, cumulative yield and yield efficiency of ten plum cultivars, in the fifth and sixth years after planting. Data for fruit weight are the average at 2006 and 2007.

\begin{tabular}{|c|c|c|c|c|c|c|}
\hline \multirow{2}{*}{ Cultivar } & \multirow{2}{*}{$\begin{array}{l}\text { TCSA } \\
\left(\mathrm{cm}^{2}\right)\end{array}$} & \multirow{2}{*}{$\begin{array}{c}\text { Fruit } \\
\text { weight } \\
\text { (g) }\end{array}$} & \multicolumn{2}{|c|}{$\begin{array}{c}\text { Yield per tree } \\
(\mathrm{kg})\end{array}$} & \multirow{2}{*}{$\begin{array}{c}\text { Cumulative } \\
\text { yield } \\
\left(\text { kg tree }^{-1}\right)\end{array}$} & \multirow{2}{*}{$\begin{array}{c}\text { Yield } \\
\text { efficiency } \\
\left(\mathrm{kg} \mathrm{cm}^{-2}\right)\end{array}$} \\
\hline & & & 2006 & 2007 & & \\
\hline Čačanska Lepotica & $35.24 \mathrm{f}$ & $48.30 \mathrm{~b}$ & $9.5 \mathrm{~b}$ & $14.7 \mathrm{de}$ & $24.2 \mathrm{~b}$ & $0.687 \mathrm{a}$ \\
\hline Ruth Gerstetter & $78.89 \mathrm{a}$ & $39.51 \mathrm{~d}$ & $5.5 \mathrm{~cd}$ & $15.9 \mathrm{bcd}$ & $21.4 \mathrm{de}$ & $0.271 \mathrm{e}$ \\
\hline Čačanska Rana & $70.70 \mathrm{~b}$ & $66.70 \mathrm{a}$ & $4.5 \mathrm{ef}$ & $14.9 \mathrm{de}$ & $19.4 \mathrm{ef}$ & $0.274 \mathrm{e}$ \\
\hline Čačanska Rodna & 41.89 ef & $25.60 \mathrm{e}$ & $5.0 \mathrm{de}$ & $18.7 \mathrm{a}$ & $23.7 \mathrm{bc}$ & $0.566 \mathrm{~b}$ \\
\hline Stanley & 49.24 cde & $37.68 \mathrm{~d}$ & $10.5 \mathrm{a}$ & $16.5 \mathrm{bc}$ & $27.0 \mathrm{a}$ & $0.548 \mathrm{~b}$ \\
\hline d'Agen & $46.89 \mathrm{de}$ & $23.93 \mathrm{f}$ & $3.7 \mathrm{fg}$ & $14.7 \mathrm{de}$ & $18.4 \mathrm{f}$ & $0.392 \mathrm{~d}$ \\
\hline Čačanska Najbolja & $79.03 \mathrm{a}$ & $50.80 \mathrm{~b}$ & $6.0 \mathrm{c}$ & $16.7 \mathrm{~b}$ & $22.7 \mathrm{bcd}$ & $0.287 \mathrm{e}$ \\
\hline Opal & $57.33 \mathrm{c}$ & $24.04 \mathrm{ef}$ & $3.5 \mathrm{~g}$ & $13.9 \mathrm{e}$ & $17.4 \mathrm{f}$ & $0.303 \mathrm{e}$ \\
\hline Bluefree & $53.13 \mathrm{~cd}$ & $49.59 \mathrm{~b}$ & $4.2 \mathrm{efg}$ & $15.3 \mathrm{~cd}$ & $19.5 \mathrm{ef}$ & $0.367 \mathrm{~d}$ \\
\hline Violeta & $44.76 \mathrm{de}$ & $43.70 c$ & $4.7 \mathrm{de}$ & $17.0 \mathrm{~b}$ & $21.7 \mathrm{~cd}$ & $0.485 c$ \\
\hline
\end{tabular}

Data with the same letter in columns are not significantly different by Duncan's multiple range test at $p \leq 0.05$.

In general, tree growth or vigour as a genetic characteristic may be influenced in the first years after by some other factors as quality of nursery stock, particular requirements of the cultivar for tree training, level of yields (precocity) etc. (Blažek and Pištěková, 2009). Also, above authors reported that exact description of cultivars in this aspect requires a much longer monitoring period in several respective locations for a valid comparison of results.

The FW is a major quantitative inherited factor determining yield, fruit quality and consumer acceptability (Crisosto et al., 2004). Data in Table 1 showed that significantly highest value was found in 'Čačanska Rana' and the lowest in 'd'Agen'. All reminding cultivars could be classified like plums with medium fruit size, which is in agreement with previous work carried out in plum (Blažek and Pištěková, 2009). The FW and its variation recorded in our study corresponded quite well to data observed in literature (Sosna, 2002; Nenadović-Mratinić et al., 2007a), although the mean FW was generally a little smaller. This could be explained by intensive tree shaping in this trial leading to higher yield efficiency in a majority of cultivars. A greater disagreement in comparison to published data could be stated in 'Bluefree' that should have possessed very large fruits, sometimes reaching weights up to $70 \mathrm{~g}$ (Blažek and Pištěková, 2009). Also, previous works on plum in a HDP reported a high variability among cultivars regarding this parameter (Sosna, 2002; Meland, 2005; Peppelman et al., 2007).

There were significant differences in $\mathrm{YT}$ and $\mathrm{CY}$ among cultivars (Table 1). Also, YT increased from 2006 to 2007. The greatest YT in 2006 and in 2007 was recorded in 'Stanley' and 'Čačanska Rodna', respectively, and the smallest in 'Opal' in both years. The highest CY was observed in 'Stanley', while the lowest values had 'Opal' and 'd'Agen'. The best values of YE were recorded in 'Čačanska Lepotica'. This confirms previous reports showing that the higher YE of 'Čačanska Lepotica' resulted from its low vigour and high yield (Milosevic et al., 2009). Also, good YE values had 'Čačanska Rodna' and 'Stanley'. The poorest YE in our study was recorded in several cultivars such as 'Ruth Gerstetter', 'Čačanska Rana', 
'Čačanska Najbolja' and 'Opal', respectively (Table 1). This is probably due to their high vigour and so high TCSA, and also low yield (Singh-Sidhu and Kaundal, 2005; Peppelman et al., 2007). Meland (2005) reported that 'Opal' in the fourth leaf in HDP had significantly smaller fruits, and trees gave 15 tons per hectare, which confirmed our results. In general, low values of YE and high TCSA values showed that 'Belošljiva' rootstock in our study induced relatively high vigour. Obtained results cannot give us a final answer to all questions that we have asked ourselves in this investigation. However, the various researchers indicated that it is possible to increase yield and high fruit by high density and utilizing dwarf rootstock. From this point, the investigation of possible usage of semi-dwarfing and dwarfing rootstocks for plum gave promising results (Gaash et al., 1989; Peppelman et al., 2007). Generally, plum cropping in our study can be considered a very good yield compared to the yields of $8.6 \mathrm{~kg}$ tree ${ }^{-1}$ that were obtained in the conventional Serbian plum orchards (NenadovićMratinić et al., 2007a).

Table 2. Leaf major nutrient content at 120 DAFB for ten plum cultivars at the five and six year after planting (average values)

\begin{tabular}{lccccc}
\hline Cultivars & $\begin{array}{c}\text { Nitrogen } \\
\mathbf{( \% )}\end{array}$ & $\begin{array}{c}\text { Phosphorus } \\
\mathbf{( \% )}\end{array}$ & $\begin{array}{c}\text { Potassium } \\
\mathbf{( \% )}\end{array}$ & $\begin{array}{c}\text { Calcium } \\
\mathbf{( \% )}\end{array}$ & $\begin{array}{c}\text { Magnesium } \\
\mathbf{( \% )}\end{array}$ \\
\hline Čačanska Lepotica & $2.49 \mathrm{~g}$ & $0.20 \mathrm{e}$ & $1.92 \mathrm{~h}$ & $2.13 \mathrm{~g}$ & $0.30 \mathrm{i}$ \\
Ruth Gerstetter & $2.64 \mathrm{e}$ & $0.15 \mathrm{~g}$ & $2.17 \mathrm{c}$ & $2.39 \mathrm{~b}$ & $0.33 \mathrm{~g}$ \\
Čačanska Rana & $2.99 \mathrm{c}$ & $0.25 \mathrm{c}$ & $2.31 \mathrm{~b}$ & $2.23 \mathrm{f}$ & $0.39 \mathrm{e}$ \\
Čačanska Rodna & $2.34 \mathrm{~h}$ & $0.27 \mathrm{a}$ & $2.09 \mathrm{e}$ & $2.43 \mathrm{a}$ & $0.44 \mathrm{~b}$ \\
Stanley & $2.56 \mathrm{f}$ & $0.25 \mathrm{c}$ & $2.11 \mathrm{~d}$ & $1.91 \mathrm{j}$ & $0.43 \mathrm{c}$ \\
d'Agen & $3.11 \mathrm{~b}$ & $0.27 \mathrm{a}$ & $2.00 \mathrm{~g}$ & $2.28 \mathrm{e}$ & $0.38 \mathrm{f}$ \\
Čačanska Najbolja & $3.34 \mathrm{a}$ & $0.19 \mathrm{f}$ & $2.08 \mathrm{f}$ & $2.11 \mathrm{~h}$ & $0.31 \mathrm{~h}$ \\
Opal & $2.87 \mathrm{~d}$ & $0.22 \mathrm{~d}$ & $2.97 \mathrm{a}$ & $1.98 \mathrm{i}$ & $0.43 \mathrm{c}$ \\
Bluefree & $2.98 \mathrm{c}$ & $0.26 \mathrm{~b}$ & $2.17 \mathrm{c}$ & $2.38 \mathrm{c}$ & $0.47 \mathrm{a}$ \\
Violeta & $2.63 \mathrm{e}$ & $0.22 \mathrm{~d}$ & $2.11 \mathrm{~d}$ & $2.33 \mathrm{~d}$ & $0.42 \mathrm{~d}$ \\
\hline
\end{tabular}

Data with the same letter in columns are not significantly different by Duncan's multiple range test at $p \leq 0.05$.

\subsection{Leaf major nutrient content and DOP index}

Significant differences among cultivars regarding leaf macronutrients content were found (Table 2). The highest $\mathrm{N}$ content was recorded in leaves of 'Čačanska Najbolja', followed by 'd'Agen', 'Čačanska Rana', 'd'Agen' etc. The lowest leaf $\mathrm{N}$ content was observed in 'Čačanska Rodna'. Similar tendencies with regard to differences in leaf $\mathrm{N}$ content due to plum cultivars has been previously described (Singh-Sidhu and Kaundal, 2005).
The leaf P content also significantly differed among cultivars. Higher content was recorded in 'Čačanska Rodna' and 'd'Agen', and lower in 'Čačanska Najbolja'. Leaf of rest cultivars had intermediate P values, which is in agreement with previous work in plum (Leece, 1975).

The percentage of $\mathrm{K}$ content on the leaves varied depending on the cultivar, and significant differences were found according to the statistical analysis (Table 2). 
The highest value was found in 'Opal', and the lowest in 'Čačanska Lepotica'. Leaf Ca content was higher in 'Čačanska Rodna', intermediate in 'd'Agen' and 'Violeta', and lower in 'Opal'. The Mg content was higher in 'Bluefree', and lower was shown in 'Čačanska Lepotica'. Previous work on plum also reported a high variability among cultivars regarding this parameter (Sánchez-Alonso and Lachica, 1987).

Table 3. The DOP index determined from leaf macronutrients at 120 DAFB in ten plum cultivars at the five and six year after planting (average values)

\begin{tabular}{lccccc}
\hline Cultivars & Nitrogen & Phosphorus & Potassium & Calcium & Magnesium \\
\hline Čačanska Lepotica & -7.7 & +2.6 & -16.5 & -5.3 & -45.4 \\
Ruth Gerstetter & -2.2 & -23.1 & -5.6 & +6.2 & -40.0 \\
Čačanska Rana & +10.7 & +28.2 & +0.4 & -0.9 & -29.9 \\
Čačanska Rodna & -13.3 & +38.5 & -9.1 & +8.0 & -20.0 \\
Stanley & -6.9 & +28.2 & -8.3 & -15.1 & -21.8 \\
d'Agen & +15.2 & +38.5 & -13.0 & +1.3 & -30.9 \\
Čačanska Najbolja & +23.7 & -2.6 & -9.6 & -6.2 & -43.6 \\
Opal & +6.3 & +12.8 & +29.1 & -12.0 & -21.8 \\
Bluefree & +10.4 & +33.3 & -8.3 & +5.8 & -14.5 \\
Violeta & +3.3 & +12.8 & -8.3 & +3.6 & -23.6 \\
\hline
\end{tabular}

Leaf composition standards for plum cultivar trees, based on mid-shoot leaves sampled at 120 DAFB (Leece, 1975; Shear and Faust, 1980). Sign (-) indicates lower content than optimum, while sign $(+)$ indicates higher content than optimum.

As given in Table 3, important group of evaluated cultivars including 'Čačanska Lepotica', 'Ruth Gerstetter', 'Stanley' and 'Čačanska Rodna' showed lower leaf $\mathrm{N}$ contents than normal, whereas other cultivars contained higher content than optimum according to Shear and Faust (1980). Moreover, greater $\mathrm{N}$ deficiency and excess was recorded in 'Čačanska Rodna' and 'Čačanska Najbolja', respectively. In our trial, there were a moderate content of organic matter and low $\mathrm{N}_{\text {TОт }}$ content in the soil. On the other hand, CAN fertilizer in quantities of $300 \mathrm{~kg} \mathrm{ha}^{-1}$, i.e. $81 \mathrm{~kg}$ $\mathrm{N}_{\text {тот }}$ ha $^{-1}$ to the beginning of vegetative cycle in this orchard was not enough to provide the optimal content of $\mathrm{N}$ in the leaves of 'Čačanske Lepotica', 'Ruth Gerstetter', 'Čačanska Rodna' and 'Stanley'. It is necessary to take into consideration the $60 \mathrm{~kg} \mathrm{~N}_{\text {тот }} \mathrm{ha}^{-1}$ from $400 \mathrm{~kg} \mathrm{NPK} \mathrm{ha}^{-1}$ mineral fertilizer. Furthermore, deficit $\mathrm{N}$ indicative of $\mathrm{N}: \mathrm{P}$ and $\mathrm{N}: \mathrm{K}$ imbalances, which is in accordance with previous work in plum (Weinbaum et al., 1994). The excess of $\mathrm{N}$ content in the leaves of the rest cultivars showed that fertilization was not adequate, as previously reported (Leece, 1975; Sánchez-Alonso and Lachica, 1987).

Most of the cultivars, except 'Ruth Gerstetter' and 'Čačanska Najbolja', showed leaf P values higher than optimum. In the soil of our trial there was high content of available $\mathrm{P}_{2} \mathrm{O}_{5}$. In addition, NPK fertilizer with $15 \% \mathrm{P}$ was used. The excessive leaf $\mathrm{P}$ found in all cultivars, except 'Ruth Gerstetter' and 'Čačanska Najbolja', was attributed to an excessive P fertilization in the growing conditions. This tendency has also been detected in previous stone fruit trials (Jiménez et al., 2004; Zarrouk et al., 2005).

Contrary to the DOP index of leaf $\mathrm{P}$ values, $\mathrm{K}$ content in plum leaves was lower than adequate for all cultivars, except 'Čačanska Rana' and 'Opal'. In fact, decreased leaf $\mathrm{K}$ was previously associated with heavier cropping rootstocks for plum (Weinbaum et al., 1994). 
This higher and/or lower content has also been detected in plum (Leece, 1975; Shear and Faust, 1980; Sánchez-Alonso and Lachica, 1987), and it was attributed to an excessive $\mathrm{K}$ fertilization in the growing conditions. Similar tendencies for leaf $\mathrm{K}$ content were previously described in apple (von Bennewitz et al., 2011).

As for leaf Ca content, half of the cultivars evaluated ('Čačanska Lepotica', 'Čačanska Rana', 'Stanley', 'Čačanska Najbolja' and 'Opal') had lower values than optimum. This can be explained by the very low mobility of $\mathrm{Ca}$ in the plant, and it implies a naturally low uptake of $\mathrm{Ca}$ and storage as $\mathrm{Ca}$ pectate (von Bennewitz et al., 2011). However, leaf of rest cultivars had higher $\mathrm{Ca}$ levels than normal. The leaf $\mathrm{Mg}$ content was lower than normal in all plum cultivars. In all cultivars, leaf $\mathrm{Ca}$ and $\mathrm{Mg}$ contents were consistently inadequate. Leaf $\mathrm{Mg}$ levels were on the deficient range. In the case of $\mathrm{Ca}$, the deficiency of this element is generally induced by antagonism with some element such as Mg (Zarrouk et al., 2005) or $\mathrm{K}$ (von Bennewitz et al., 2011). Also, Ca counteracts the potential harmful effects of $\mathrm{Mg}$ and other divalent cations (Shear, 1975).

There were significant differences among cultivars concerning the $\Sigma$ DOP index for major nutrients in leaves at 120 DAFB (Figure 1). The highest $\Sigma$ DOP index values were found in 'd'Agen', and the lowest in 'Violeta'. Values of $\Sigma$ DOP index for other cultivars were intermediate. According to the $\Sigma$ DOP index, 'd'Agen' showed a wider imbalance in nutritional values, whereas 'Violeta' showed lower intensity of imbalances among leaf major nutrients. Previous works, carried out by Jiménez et al. (2004) and Zarrouk et al. (2005), did not find a significant differences for nutritional balance values, i.e. $\Sigma$ DOP, among peaches and sweet cherries. The differences between our results and those of above authors could be explained by differences in the plant material, pedo-climatic conditions and cultural practices, as previously reported (Leece, 1975; Shear and Faust, 1980).

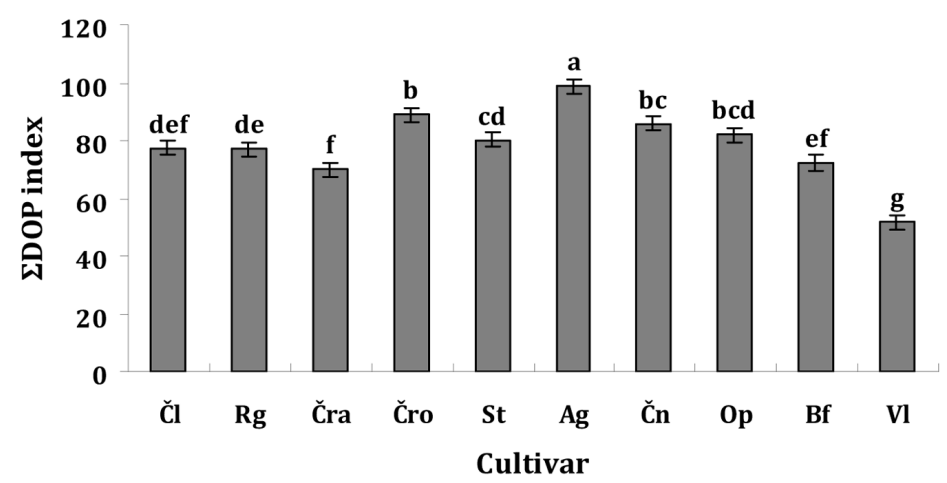

Figure 1. DDOP index determined from leaf macronutrient content at 120 DAFB in ten plum cultivars. The different letter(s) at the top of bars indicates significant differences among cultivars for $\Sigma$ DOP by Duncan's multiple range test at $p \leq 0.05$. Abbreviations: Čl: Čačanska Lepotica; Rg: Ruth Gerstetter; Čra: Čačanska Rana; Čro: Čačanska Rodna; St: Stanley; Ag: d'Agen; Čn: Čačanska Najbolja; Op: Opal; Bf: Bluefree; Vl: Violeta. 


\section{Conclusions}

Plum cultivars analyzed in this study exhibited significant differences in the tree vigour, fruit weight, productivity and leaf content of major nutrient at 120 DAFB. Leaf major nutrient accumulation was non-uniform, being cultivar-dependent, and resulted in nutrient deviation from optimum values. The $\Sigma$ DOP index showed a nutrient imbalance in all cultivars, suggesting that inadequate mineral fertilization was employed in this study. The results of plum trials under HDP system in limited soil conditions are promising. The vegetative growth was relatively reduced, production is good, starts early and fruit size is good too.

\section{Acknowledgements}

This study is part of the project 31064 funded by Ministry of Education, Science and Technological Development of the Republic of Serbia. The authors wish to thanks Aleksandra Milošević for her technical assistance; and the anonymous reviewers for their invaluable suggestions and comments.

\section{References}

Blažek, J., Pištěková, I. 2009. Preliminary evaluation results of new plum cultivars in a dense planting. Hortic. Sci. 36, 45-54.

Chaplin, M.H., Westwood, M.N., Roberts, A.N. 1972. Effects of rootstock on leaf element content of Italian prune (Prunus domestica L.). J. Am. Soc. Hortic. Sci. 97, 641-644.

Crisosto, C.H., Garner D., Crisosto, G.M. Bowerman E. 2004. Increasing 'Blackamber' plum (Prunus salicina Lindley) consumer acceptance. Postharvest Biol. Tec. 34, 237-244.

FAOSTAT. 2013. Available at http://www.faostat.fao.
Gaash, D., David, I., Ran, I. 1989. Plum high density planting - 10 year trials. Acta Hortic. 243, 331-336.

Jiménez, S., Garín, A., Gogorcena, Y., Betrán, J.A., Moreno, M.A. 2004. Flower and foliar analysis for prognosis of sweet cherry nutrition: Influence of different rootstocks. J. Plant Nutr. 27, 701-712.

Leece, D.R. 1975. Diagnostic leaf analysis for stone fruit. 4. Plum. Aust. J. Exp. Agr. Anim. Husb. 15, 112-117.

Meland, M. 2005. High density planting systems of European plums - the effect of growth and productivity of three cultivars after nine years. Acta Agr. Scand. B - Plant Soil Sci. 55, 51-57.

Milosevic, T., Glisic, I., Milosevic, N. 2009. Dense planting effect on the productive capacity of some plum cultivars. Acta Hortic. 825, 485-490

Milosevic, T., Milosevic, N. 2010. The effect of organic fertilizer, composite NPK and clinoptilolite on changes in the chemical composition of degraded vertisol in Western Serbia. Carpath J. Earth Env. Sci. 5, 25-32.

Milosevic, T., Milosevic, N., Mratinic, E. 2010a. Morphogenic variability of some autochthonous plum cultivars in Western Serbia. Braz. Arch. Biol. Techn. 53, 1293-1297.

Milosevic, M.T., Glisic P.I., Milosevic T.N., Glisic S.I. 2010b. Plum pox virus as a stress factor in the vegetative growth, fruit growth and yield of plum (Prunus domestica L.) cv. 'Cacanska Rodna'. Eur. J. Plant Pathol. 126, 73-79.

Montañés, L., Heras L., Sanz, M. 1991. Desviacién del óptimo porcentual (DOP): nuevo índice para la interpretación del análisis vegetal. An. Aula Dei, 20, 93-107

Nenadović-Mratinić, E., Milatović, D., Djurović, D. 2007a. Biological characteristics of plum cultivars with combined traits. Voćarstvo. 41, 31-35. 
Nenadović-Mratinić, E., Milatović, D., Djurović, D., Jovičić, Z. 2007b. Morphological characteristics of fruiting twigs in plum cultivars (Prunus domestica L.). Voćarstvo. 41, 51-56.

Peppelman, G., Kemp, H., Balkhoven-Baart, T. M. J., Groot, J. M. 2007. Towards high density plum growing - agronomic and economic performance of plum (Prunus domestica L.) on 'VVA-1' rootstock. Acta Hortic. 734, 225-234.

Sánchez-Alonso, F., Lachica, M. 1987. Seasonal trends in the elemental content of plum leaves. Commun. Soil Sci. Plant Anal. 18, 31-43.

Sanz, M. 1999. Evaluation of interpretation of DRIS system during growing season of the peach tree: Comparison with dop method. Commun. Soil Sci. Plant Anal. 30, 1025-1036.

Shear, C.B. 1975. Calcium-related disorders of fruits and vegetables. HortScience. 10, 361-365.

Shear, C.B., Faust, M. 1980. Nutritional ranges in deciduous tree fruits and nuts. Hortic. Rev. 2, 142163.

Singh-Sidhu, L., Kaundal, G.S. 2005. Effect of planting density on fruit yield, foliar nutrient content and root distribution of plum (Prunus salicina Lindl.) cv. 'Satluj Purple'. Acta Hortic. 696, 299-302.
Sosna, S. 2002. Growth cropping of four plum cultivars on different rootstocks in South Western Poland. J. Fruit Ornam. Plant Res. 10, 95-103.

Vitanova, I., Dimkova, S., Ivanova, D. 2004. Vegetative and reproductive parameters of introduced plum cultivars. J. Fruit Ornam. Plant Res. 12, 257-262.

von Bennewitz, E., Cooper, T., Benavides, C., Losak, T., Hlusek, J. 2011. Response of "Jonagold" apple trees to $\mathrm{Ca}, \mathrm{K}$ and $\mathrm{Mg}$ fertilization in an andisol in southern Chile. J. Soil Sci. Plant Nutr. 11, 71-81.

Weinbaum, S.A., Niederholzer, A.J.F., Ponchner, S., Rosecrance, C.R., Carlson, M.R., Whittlesey, C.A., Muraoka, T.T. 1994. Nutrient uptake by cropping and defruited field-grown 'French' prune trees. J. Am. Soc. Hortic. Sci. 119, 925-930.

Zarrouk, O., Gogorcena, Y., Gómez-Aparisi, J., Betrán, J.A., Moreno, M.A. 2005. Influence of almond $\mathrm{x}$ peach hybrids rootstocks on flower and leaf mineral concentration, yield and vigour of two peach cultivars. Sci. Hortic. 106, 502-514. 